\title{
Evolution and perspectives of electronic markets
}

\author{
Rainer Alt ${ }^{1}$ \\ Published online: 1 April 2020 \\ (C) The Author(s) 2020
}

The journal Electronic Markets is celebrating its 30th anniversary. It has experienced an exciting development from a project newsletter to an international academic journal. This journey had already been summarized in an editorial after the first 25 years (Alt et al. 2015). Another five years later the field of electronic markets has progressed further and proves to be more relevant than ever before. For example, worldwide electronic retail sales have more than doubled from 1,548 billion USD in 2015 to 3,535 billion in 2019 and projections foresee a continued strong growth to 6,542 billion USD in 2023 (eMarketer 2019). Measured by market value, seven businesses among the ten largest companies worldwide were operators of electronic platforms (Forbes 2019) and researchers stated that "digital platforms already dominate the top 10 of the world's most valuable firms" (Demary and Rusche 2018, p. 4). They confirm that platforms are mainly driven by digitalization, "the number one megatrend at the moment" (Demary and Rusche 2018, p. 5). Digitalization is a phenomenon that influences the life of individuals, the operation of organizations and societal processes as a whole (Alt 2018). In fact, it might be the largest difference compared to the situation five years ago that digital platforms have now become visible to everybody. This editorial aims to reflect on the evolution of digital (market) platforms in general as well as on some more specific directions. Following an established opinion, it recognizes network effects as a major driver of the platform evolution and presents an overview on research topics that are considered necessary in the future evolution of digital platforms. To allow a more diverse discussion on the evolution, this jubilee issue has a unique format, which will be described in more detail below.

Rainer Alt

rainer.alt@uni-leipzig.de

1 Information Systems Institute, Leipzig University, Grimmaische Str. 12, 04109 Leipzig, Germany

\section{Phases in electronic markets evolution}

To start with, most electronic markets are digital platforms. Following a high-level understanding, a digital platform mediates social and economic interactions online (Kenney and Zysman 2016). Looking back, this mediation of social and economic interactions is based on various key technologies. For example, the support of social interactions more or less dates back to electronic mail and mailing lists in the $1960 \mathrm{~s}$, which were followed by internet mail and groupware systems in the 1990s and the multimedia and social interaction services that evolved since the 2000s. Regarding economic interactions, various technologies may be distinguished in the area of electronic commerce and (the broader) electronic business (see Alt and Zimmermann 2015). As explained below, electronic market platforms may be conceived as digital platforms that link transacting parties via a centralized information system that uses a certain infrastructure technology. Three types of such infrastructure technologies may be observed:

- Proprietary infrastructure. In the 1960s, first electronic marketplaces emerged in the airline industry (Cheng 2016) with systems in other industries such as agriculture, banking and retailing to follow. These early electronic marketplaces were largely based on proprietary technological infrastructures (e.g. based on so-called valueadded network services or videotex systems), which due to their proprietary nature - restricted the diffusion of these platforms. However, they already shed light on the advantages of the electronic marketplace concept, which mainly reduced transaction costs due to efficiencies in communication among multiple buyers and sellers, in higher market transparency and more efficient contracting as well as clearing and settlement processes. Malone et al. (1987) summarized these advantages as electronic communication, brokerage and integration effects. 
- Internet infrastructure. The limitation of proprietary infrastructures disappeared with the internet as a ubiquitous infrastructure, which was able to link businesses and individuals alike. This constitutes the second major wave of electronic marketplaces and by the year 2000, the electronic markets database operated by the research firm Berlecon included 1,140 entries for B2B marketplaces with 788 originating from the US market (Berlecon 2000). A downturn occurred after 2001 and many internet startups founded during the so-called "new economy" disappeared. Although the number of electronic marketplaces decreased sharply, the marketplace model in the business (e.g. Aeroexchange, Hubwoo) as well as in the consumer (e.g. Amazon, Ebay) world survived. Over the years, those systems have enhanced their scope of electronic transaction support (e.g. payments, electronic data interchange), which further helped in making them attractive for buyers and sellers.

- Ecosystems infrastructure. A third phase may be observed since the mid-2000s, when social media and ecosystems appeared. Increasingly, technologies like electronic catalogs as well as matching, scoring, payments and logistics systems were provided on various electronic platforms. They created powerful digital business solutions, which transformed many industries and are now almost omnipresent. Among the wellknown platforms illustrating the broad nature of this business model (e.g. Parker et al. 2016) are operating system platforms (e.g. Apple iOS, Google Android, Microsoft Windows), social networking platforms (e.g. Facebook, Tiktok, Twitter) and many transaction platforms (e.g. Alibaba, Amazon, JD). These different platforms are not independent from each other, but have emerged as ecosystems where compatible platforms are interconnected and share key services (e.g. payments, logistics) are shared. With these ecosystem infrastructures, the number of potential participants for electronic marketplaces grew. They not only included individuals and organizations as participants, but also the applications and electronic devices that provided and consumed data. Consequently, electronic markets experienced another surge with numerous app stores and multi-sided solutions as examples.

\section{Observations on the move to markets}

As confirmed in the article on disintermediation included in this issue (Wigand 2020), the evolution of electronic markets was driven by the attractiveness inherent in their topology and their function as facilitators of transactions. The hub structure reduced the complexity of relationships from $n(n-1)$ to $n$ and the centralized market database together with search, matching and settlement functionalities lowered transactions costs. Again, the research of Malone et al. (1987, p. 492ff) proved to be influential regarding the interpretation of these reductions in transaction cost. They formulated stages for the evolution of electronic markets and for the evolution of electronic hierarchies. The former comprised the move from biased to unbiased and ultimately to personalized markets, while the latter described a shift from stand-alone to linked and then to shared databases. Although the authors argue the benefits of both evolution paths, they advocate an overall move towards electronic markets (Malone et al. 1987, p. 496): "Market forces make it likely that biased electronic sales channels (whether electronic hierarchies or biased electronic markets) for nonspecific, easily described products will eventually be replaced by unbiased markets." As it turns out, there is evidence confirming these expectations, but the explanations are more complex and differentiated (e.g. Klein and Alt 2015, Standing et al. 2010):

- Multi-sided markets. The first development refers to the move from single-sided platforms to multi-sided markets. Single-sided models may be conceived as supermarkets where one actor takes possession of goods in order to resell them (Staykova and Damsgaard 2014). In a multisided market, other sellers are present on the platform as well. A well-known example is Amazon, which not only offers an assortment of goods in their own catalog, but introduced the Amazon Marketplace in 2000 as a multisided platform (Ritala et al. 2014). Other US retailers, such as Walmart and, more recently, Target (Green 2019) or the German retailer Real (Ecommerce Germany 2019) followed a similar path and their own established multisided market platforms. This move opens a new business model, which yields these companies revenues for facilitating transactions even with competitors.

- Biased markets. The development from biased to unbiased electronic marketplaces is more difficult. Although electronic marketplaces will be unbiased after regulators imposed industry-wide rules (e.g. in the financial or the airline industry), influencing the listing is often tempting for marketplace operators. In many B2C marketplaces, we observe marketplace operators that place their offerings above those of competitors, thereby significantly increasing the probability of selling them. Among the examples at Amazon are sponsored or promoted items ("Amazon's Choice") as well as AmazonBasics products. Similarly, the travel site Booking.com lists as default setting "Our Top Picks" first and mentions that this ranking "is created through a complex ever-changing and evolving system (algorithm) that considers a multitude of criteria in order to match searchers and accommodations in an optimal 
way." (Booking.com 2020). At least, buyers in these and other marketplaces are able to obtain unbiased listings (e.g. lowest price first), but they have to actively and deliberately choose this option.

- Personalized markets. Another development expected by Malone et al. was the move from unbiased to personalized marketplaces. Meanwhile, advances in big data and artificial intelligence technologies have led marketplace operators to personalize their offerings based on knowledge extracted from past transactions of many participants. For example, Booking.com notes that "The actual ranking will be different for each customer and for each search" (Booking.com 2020), which confirms the analysis of Glassberg and Merhout (2007), whereas there is a move to personalized marketplaces that offer customized interfaces and offerings in the $\mathrm{B} 2 \mathrm{C}$ arena. However, it suggests that biased as well as unbiased marketplaces may be personalized and that this is no linear trajectory. Obviously, a key requirement for personalization would be that the criteria applied are transparent and capable of being influenced by the users.

- Crowdsourcing markets. In the field of B2B transactions, several analyses have suggested that the differences point at closer relationships between participants than in the B2C area (e.g. Clemons et al. 1993, Glassberg \& Merhout 2007, Klein and Alt 2015). It shows that the integration effect, which is particularly present in electronic hierarchies, is relevant for sharing risks (e.g. for joint innovations) and safeguarding against so-called non-contractible issues (e.g. quality and flexibility). This would rather support the "move-to-the-middle" than the pure "move-to-the-market" hypothesis for offerings that feature a higher specificity and complexity of product description. At the same time, numerous crowdsourcing platforms (e.g. Howcroft and Bergvall-Kåreborn 2019) have given rise to a more market-like sourcing of professional services. They indicate that the vision of the e-lance economy anticipated in 1998 (Malone and Laubacher 1998) may slowly have become a reality and that more markets seem to present in the B2B arena as well. There is evidence (Berg et al. 2019) that decentralized technological infrastructures, such as blockchain, also point in this direction.

- Hybrid markets. Finally, much attention was observed during the past years regarding the relationship between online and offline business models. The analysis of Glassberg and Merhout (2007, p. 53) mentioned that despite electronic markets are being used for comparison shopping, there are reasons, such as transaction security, haptic experience or brand loyalty that lead consumers to purchase offline. In fact, many online retailers established offline presences (e.g. Amazon Go, Whole Foods) and offline retailers established online presences in recent years (e.g. Target, Walmart). Innovative combinations of both models have loomed that define the (hybrid) "marketplaces of the future" (Böger et al. 2019). The situation resembles the relationship between paper ( $p$ ) and electronic (e) books. Although e-books were believed to substitute p-books, this did not happen. However, the relationship changed and "digital technology is providing mechanisms that enhance our ability to produce and distribute both p-books and ebooks" (Phillips 2020, p. 851). Thus, it may be assumed that electronic markets are often complementary in nature - at least if the product or service has physical elements.

\section{Critical mass challenges}

Overall, these developments tend to confirm the growing role of electronic markets, which is also reflected in projections whereas global revenues from marketplace platform providers are expected to double from 2017 to 2022 (Alaimo 2018). Besides creating electronic markets where analog markets previously existed (e.g. banking, retailing) this also includes the creation of new market segments (Klein and Alt 2015). For example, it applies to the multisided market model, which is a key characteristic of the sharing economy (Puschmann and Alt 2016). However, the evolution of electronic marketplaces has not been constant. It has rather been a rough ride for many actors in the market. Not only did numerous initiatives exit the market in the 2001 turmoil, but it has been observed that "the problem is that platforms fail at an alarming rate [...] despite the huge upside opportunities that platforms offered" (Yoffie et al. 2019). Besides flaws that may be included in every business model, platform business models have a specific logic that is linked with the network effect (e.g. van Alstyne et al. 2016). The success of platforms inherently depends on the participation on both sides of the platform. These business models follow a different logic since reaching a critical mass of (active) participants and nurturing communities of users is critical for competing in the platform market. A recent editorial on platform competition elaborated on this competition among platforms (Alt and Zimmermann 2019) and pointed at the integration of multiple platforms within larger ecosystems. It was suggested that a platform's competitive advantage is created by horizontally and vertically linking meta-platforms, transaction platforms, and service platforms, which are largely complementary in nature and have positive mutual effects. While the notion of critical mass may appear plausible, previous research on this topic highlights the challenges:

- Critical mass is a social construct. The general observation is that the critical mass is difficult to calculate. Also defined as the so-called tipping point, it denotes the 
"minimum number of users [that] have adopted the technology solution" and it is after reaching this number that network effects kick in (Tiwana 2014, p. 36). Although economists have developed models to calculate the tipping point, it ultimately remains a social construct, which is influenced by many aspects. Among these are prices charged, platforms features and agent's tastes (SánchezCartas and León 2019) as well as the "watching the group" effect, which states that "individuals based their choice on what they expect the others to decide" (Allen 1988, p. 260).

- Critical mass favors successful platforms. Following Tiwana (2014, p. 34) network effects feature two "nuanced properties [...]: direction and sidedness". The former refers to the course of the exponential curve, which may be positive, negative or a combination of both (e.g. when more users clog an infrastructure). The latter recognizes that network effects may occur on the same side of a platform (e.g. more users attracting more users) or across platform sides (e.g. more users attracting more sellers). Both effects may also be present across platforms and support the complementary nature of platforms within an ecosystem. Ultimately, there is only limited space for many successful competing platforms and critical mass tends to crowd-out less successful platforms, thus favoring monopolistic structures.

- Critical mass needs to be nurtured. To reach critical mass, platform providers require users on both sides of the platform and will aim to provide incentives to them. The decision, which side to subsidize (first), has been recognized as a common procedure for digital platforms (Yoffie et al. 2019). It follows the observation of the critical mass frontier (Evans and Schmalensee 2016), whereas attaining a critical mass does not necessarily require reaching a high number of participants on both platform sides. In fact, "the higher the number in one group, the smaller is the number of users needed in the other group" (Demary and Rusche 2018 , p. 13). For example, this phenomenon is present when the provider of an operating platform decides to give away the necessary hardware to access the platform and the services on the platform for free or for low prices.

- Critical mass needs active users. The absolute number of participants on a platform is not sufficient in explaining the critical mass effects since active participation is necessary for attaining liquidity. This is why many platforms explicitly report "active users" and aim to provide incentives to them (e.g. preferred membership status with cost benefits). In particular, in the business domain it has been observed that decisions to participate in a platform are made by other individuals than those who actually use the platform in their daily work (see the example for transportation markets reported by Alt and Klein (1999)).
- Critical mass should be sustainable. Finally, Cusumano (2020) points at the fact that despite having reached a critical mass, platforms need to constantly enhance their offering in view of other competitors aiming to reach or increase their liquidity. This pressure is reflected in the statement whereas "investors and entrepreneurs keep looking for the next blockbuster platform" (Cusumano 2020, p. 24). Obviously, sustainability also includes that the platform provider's business model yields sufficient profits once it has reached the critical mass to cover operations as well as the cost of constantly enhancing the platform.

\section{Research perspectives}

It is striking, that despite network effects are at the heart of platform models, they are not enjoying a similar explicit role in the literature that has been published in recent years on digital platforms. Based on a brief review of literature in the field of electronic markets and digital platforms (see Table 1), the findings of two recent papers (Asadullah et al. 2018, de Reuver et al. 2018) serve to structure the research perspectives in three distinct clusters. They address basic terms and concepts as well as methodological issues, but similar to the aspects discussed for the evolution of digital platforms, topics named in the reviews are only little technological in nature. Although digital platforms are based on advanced information technologies, it appears that the technology itself is not a key constraint.

The first research cluster applies to terminology (Ardolino et al. 2016, Asadullah et al. 2018, Grieger 2003, de Reuver et al. 2018, Sánchez-Cartas and León 2019). Despite the long legacy of research in the field of electronic markets, there is still a need for an improved understanding of relevant terms. For example, de Reuver et al. (2018) call for more conceptual clarity regarding the definition of the unit of research and Asadullah et al. (2018, p. 11) identified a "lack of agreement on a clear definition and conceptualization of digital platforms in the IS literature". One explanation may be that with the growing attention regarding digital platform topics in the general public, more individuals and organizations are using the terms. In many cases, the authors are not referencing the existing body of knowledge and their argumentation is motivated from various backgrounds as well as for different purposes. For the journal Electronic Markets, the following understanding has been helpful in delineating the various terms (see Fig. 1):

- Digital platforms are centralized technological (hardware and software) systems that provide core functionality among interoperable elements (de Reuver et al. 2018, p. 
Table 1 Selection of literature analyses on digital platforms and electronic markets

\begin{tabular}{|c|c|}
\hline Authors & Contents of literature survey \\
\hline Ardolino et al. 2016 & $\begin{array}{l}\text { - Methodology: literature analysis of } 112 \text { papers } \\
\text { - Perspectives in three areas: (1) conceptualization of the phenomenon, (2) categorization of different types of multi-sided } \\
\text { platforms and (3) effects of digitization on multi-sided platforms. }\end{array}$ \\
\hline Asadullah et al. 2018 & $\begin{array}{l}\text { - Methodology: literature analysis of } 96 \text { papers from } 2002 \text { to } 2017 \\
\text { - Perspectives in five areas: (1) analysis of existing definitions, (2) more methodological diversity, (3) extraction of digital } \\
\text { platform types and characteristics, (4) conceptualization of new technologies, (5) multi-dimensional analysis of digital } \\
\text { platforms. }\end{array}$ \\
\hline Coyle 2016 & $\begin{array}{l}\text { - Methodology: literature analysis with focus on policy-making } \\
\text { - Perspectives in three areas: (1) theories and evidence on digital platforms, (2) formulation of key topics for researchers, } \\
\text { policymakers and platform providers. }\end{array}$ \\
\hline de Reuver et al. 2018 & $\begin{array}{l}\text { - Methodology: literature analysis with focus on digital platforms in general } \\
\text { - Perspectives in three areas: (1) conceptual clarity on the unit of analysis, degree of digitality and the sociotechnical nature of } \\
\text { digital platforms, (2) analysis of platforms on different architectural levels and in different industry settings, (3) application } \\
\text { of methodological rigor via embedded case studies, longitudinal studies, design research and data-driven modelling and } \\
\text { visualization. }\end{array}$ \\
\hline Grieger 2003 & $\begin{array}{l}\text { - Methodology: literature analysis with focus on electronic markets and supply chain management } \\
\text { - Perspectives in two areas : (1) choice of electronic marketplace categories for supply chain management, (2) selection of } \\
\text { suitable type of electronic market relationship (transactional, information-sharing, collaborative) for supply chain } \\
\text { management. }\end{array}$ \\
\hline Hein et al. 2020 & $\begin{array}{l}\text { - Methodology: literature analysis with focus digital platform ecosystems } \\
\text { - Perspectives for research in digital platform ecosystems: (1) technical properties and value creation, (2) value capture in } \\
\text { digital platform ecosystems, (3) complementor interaction with the ecosystem, (4) Make-or-join decision in digital } \\
\text { platform ecosystems. }\end{array}$ \\
\hline Rong et al. 2018 & $\begin{array}{l}\text { - Methodology: literature analysis with focus on business ecosystems in Asia } \\
\text { - Perspectives: (1) dynamics of business ecosystems, (2) embeddedness of resources in business ecosystems, (3) } \\
\text { internationalization. }\end{array}$ \\
\hline $\begin{array}{l}\text { Sánchez-Cartas and León } \\
2019\end{array}$ & $\begin{array}{l}\text { - Methodology: literature analysis with focus on literature since } 2000 \\
\text { - Perspectives in three areas: (1) definitions used in the literature, (2) identification and classification of multi-sided platforms, } \\
\text { (3) specifics of platform business models (e.g. prices, coordination problems, platform structure, exclusivity and } \\
\text { multihoming, platforms and content and the anti-trust literature on multi-sided markets). }\end{array}$ \\
\hline Setzke et al. 2019 & $\begin{array}{l}\text { - Methodology: literature analysis of } 73 \text { papers with focus on platform openness } \\
\text { Perspectives in five areas: (1) measurement frameworks, (2) implementation mechanisms, (3) drivers for opening and } \\
\text { closing platforms, (4) trade-offs in designing openness, (5) impact of changing openness on ecosystems), perspectives and } \\
\text { areas for future research. }\end{array}$ \\
\hline Standing et al. 2010 & $\begin{array}{l}\text { - Methodology: meta-analysis of research literature on electronic markets, } 196 \text { papers from } 1997 \text { to } 2008 \\
\text { - Perspectives in five areas: (1) link between e-commerce and e-marketplaces, (2) the use of fundamental theories related to } \\
\text { electronic markets, (3) technology-focused research, (4) e-marketplace adoption and implementation issues, (5) } \\
\text { organizational implications of e-marketplace participation including strategic implications. }\end{array}$ \\
\hline Vial 2019 & $\begin{array}{l}\text { - Methodology: literature analysis of } 282 \text { papers with focus on digital transformation } \\
\text { - Perspectives in three areas: (1) framework for digital transformation, (2) role of dynamic capabilities, (3) study of ethical } \\
\text { issues. }\end{array}$ \\
\hline
\end{tabular}




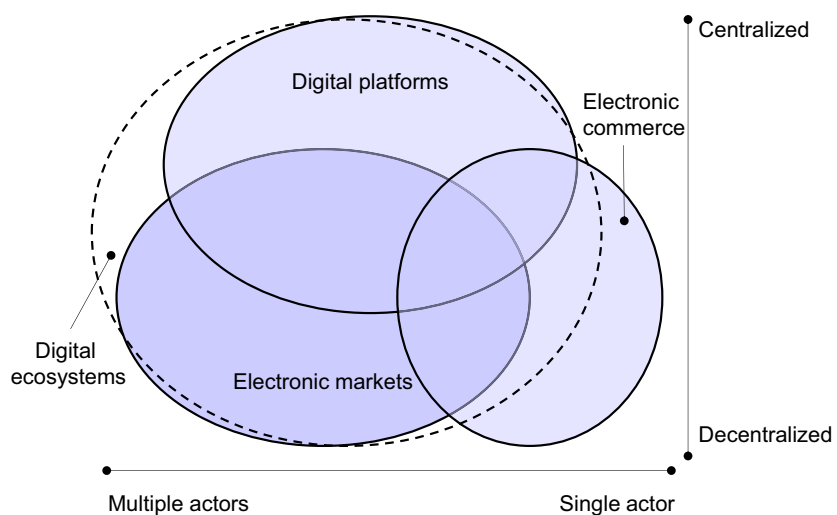

Fig. 1 Relationship of key terms in the field of electronic markets

- Electronic commerce also refers to electronically supporting the phases of economic transactions. This may occur via digital platforms as well as via electronic markets, but in addition to the multilateral settings, electronic commerce scenarios might also be bilateral in nature. A popular example is electronic data interchange where documents are communicated directly between two organizations.

The second research cluster are research concepts for analyzing and designing digital platforms (Ardolino et al. 2016, Asadullah et al. 2018, Coyle 2016, de Reuver et al. 2018, Hein et al. 2020, Grieger 2003, Rong et al. 2018, Sánchez-Cartas and León 2019, Setzke et al. 2019, Standing et al. 2010, Vial 2019). This cluster comprises a broad set of factors (e.g. design factors, dynamics, effects, benefits, risks; see also Abdelkafi et al. 2019) on various analytical levels (e.g. network and industry, organization and processes, systems and technologies). It is based on the assumption that technology is agnostic of its effects and that the same technology may be used for "good" or for "bad" purposes. This happens in a specific application context and may be influenced by the parties involved. Platform operators, such as the "big four" GAFA (Google, Apple, Facebook, Amazon) or BATX (Baidu, Alibaba, Tencent, Xiaomi), have particular influence on this direction. Digital platforms and electronic markets are socio-technical systems, but due to the interaction of multiple heterogeneous actors (i.e. consumers, suppliers, employees) the complexities are typically higher than with intra-organizational enterprise systems. This requires not only to focus on the organizational level when analyzing the impact of digital transformation, but also to consider long-term and higher-level impacts, in particular the conflicting expectations and goals of different parties contributing to the system (Vial 2019). In the same vein, Asadullah et al. (2018) advocate a broader perspective on digital platform research by pursuing more holistic approaches as well as by considering the multi-dimensional nature of digital platforms. Two articles in this issue (Osterle 2020, Clarke 2020) are examples in this direction since they call for different research perspectives and the inclusion of ethical issues. In view of the growing role of digital platforms in the society, the latter are increasingly critical to influence the development and regulation of platforms.

Attention is also required regarding the oligopolistic and even monopolistic consequences of critical mass effects on a regulatory and policy level (Coyle 2016). While one direction might be a stricter regulation of platforms and thus an artificial protection of the position of incumbents, another might be to utilize benefits of existing platforms and to support the evolution of new platforms. In particular, this applies to the European market since all dominating digital platforms are currently either US or China based. To foster the emergence of competition against these platforms, issues of power, politics and nationality the blending of public and private goods, as well as macroeconomic issues, e.g., taxation, labor and social issues, need to be considered. The opinon from Riemensperger and Falk (2020) included in this issue follows this argumentation.

Based on prior experience and the decline of dominating firms, the "sixty-four-thousand-dollar question" is which disruptive next technology will give rise to new competitors. The simple extrapolation of existing trends will undoubtedly lead us to expect more technological interoperability and more autonomously acting systems with many processes in the existing world to be digitalized. The more disruptive transformation processes are, the more will they involve uncertainty. Where the "next big thing" will originate is per se unknown, although many platform providers believe that wearables and artificial intelligence technologies could provide one direction. These technologies create new means for interacting with digital platforms and via the platform with other individuals. So-called neuro information systems could even allow the navigation based on thoughts, thus emphasizing the need for linking technological with non-technological disciplines.

Finally, in terms of methodological approach some authors call for broadening the set of applied methodologies and the object of research (e.g. Asadullah et al. 2018, de Reuver 2018, Setzke et al. 2019, Standing et al. 2010, Vial 2019). To understand the interplay of actors on digital platforms, de Reuver et al. (2018, p. 128) propose to apply embedded case studies "to compare cases within the same larger ecosystem" as well as to conduct longitudinal studies, which obtain an understanding of platform dynamics over time. Other directions are based on the data generated from traffic on the platforms, for example, with data mining and network analysis 
techniques. While these approaches are valuable in understanding past developments or interactions that have already happened, anticipating future developments will require prospective methodologies (Alt and Österle 2014). Established methodologies to "invent the future" are largely based on design science (e.g. vom Brocke and Mädche 2019), which uses prototypes and recognizes the synergies in combining of research and practice.

\section{Articles in jubilee issue}

To add to the discussion of the evolution and the perspectives in the field of electronic markets, this 30-year anniversary issue contains a collection of seventeen articles, excluding this editorial. They are organized in two main parts and include two innovations. The first ten papers belong to the jubilee section "evolution and perspectives of electronic markets" and were invited from high profile individuals with profound and long experience in the field of electronic markets. Besides a position paper and three invited papers, six papers are discussion papers that aim at presenting opinions in a much shorter format than regular position papers. The seven remaining papers include generalresearch with four papers being research papers in the "classical" format and three being research papers in a new format, called "Fundamentals" to be introduced below.

For the anniversary issue, Electronic Markets approached esteemed colleagues, who have worked in the field of electronic markets for many years and have accompanied the Electronic Markets journal on its journey. Beat Schmid was the responsible professor at the University of St.Gallen for the research project "Competence Center Electronic Markets (CCEM) at that time and the first Editor-in-Chief of Electronic Markets (1996-2007). Now retired, he contributes a critical discussion piece on "What kind of electronic markets do we deserve?" to the present jubilee issue (Schmid 2020). Hubert Osterle was Electronic Markets' Editor-in-Chief from 2006 until 2014 and, meanwhile also a retired professor from the University of St.Gallen, shares his thought-provoking vision of "Life engineering" in an invited paper (Osterle 2020). Another important person for Electronic Markets who has become a successful entrepreneur is Dorian Selz. As executive editor of the journal from 1996 to 1998 he laid the foundation for the development towards an academic journal. In his discussion piece, he presents the move "From electronic markets to data driven insights" (Selz 2020).

Like Dorian, Richard Dratva, Andreas Göldi and Martin Reck, were research assistants at the University of St.Gallen. Together with three other colleagues, Richard founded the Zurich-based software company Crealogix in 1996. With some 700 employees, the company has become an important provider of banking software, which led him to ask the question "Is open banking driving the financial industry towards a true electronic market?" in his discussion paper (Dratva 2020). Another critical opinion is contributed by Andreas, who started his entrepreneurial career by founding the web development company Namics in 1995. Since then, Andreas has initiated several other businesses and is now a venture capitalist. He reflects on "A blind spot for the dark side: the monopolies we didn't see coming" (Göldi, 2020). Finally, after finishing his doctoral thesis on electronic auctions, Martin joined the German stock exchange, where he now acts as managing director. He reports on "Xetra: the evolution of an electronic market", with Xetra being the software system of the stock exchange (Reck 2020).

In addition to these former colleagues from the University of St.Gallen, four other senior scholars from outside the University of St.Gallen share their views. In a position paper, Roger Clarke from the University of New South Wales and the Australian National University analyzes the researcher perspectives of papers published in Electronic Markets (Clarke 2020). Roger has been a long-time supporter of Electronic Markets as well as the Bled eConference, where he worked together with Andreja Pucihar. As professor at the University of Maribor in Slovenia, Andreja is the general chair of the Bled eConference and a senior editor at Electronic Markets. For this jubilee issue she has analyzed "The digital transformation journey" based on a content analysis of articles from Electronic Markets and the Bled eConference proceedings from 2012 to 2019 (Pucihar 2020). Another former senior editor of Electronic Markets is Rolf T. Wigand, who is now a retired professor at the University of Arkansas and an influential researcher on electronic commerce, in particular, the question of disintermediation. In his invited paper, he consequently asks the question "Whatever happened to disintermediation?" (Wigand 2020).

Last but not least, the jubilee issue includes two contributions from member of Electronic Markets' advisory board. The first is from Hubert Osterle, who joined the advisory board after leaving his position as Editor-inChief. The second is from Frank Riemensperger who is the chairman of Accenture Germany. Together with his colleague Svenja Falk, he shows "How to capture the B2B platform opportunity" (Riemensperger and Falk 2020). This paper recognizes that digital platforms are dominated by non-European companies and develops a positive perspective for European competitors in particular in the industrial $\mathrm{B} 2 \mathrm{~B}$ sector.

\section{Perspectives in discussion papers}

When reading the many different viewpoints in the discussion papers, it is remarkable that many positions are rather critical. One of the common issues is that electronic markets have not 
lived up to their hopes and expectations. Of particular interest and in contrast to many research agendas presented in the literature was the question of openness (i.e. only one research listed in Table 1 explicitly focused on openness). It links to one of the effects of critical mass mentioned above, which sees oligopolistic or even monopolistic structures instead of open markets as outcomes. This includes possible negative impacts on innovation and the freedom of users, as Göldi remarks. Schmid even uses the term 'parasitic' players to describe today's electronic markets' conditions, which are far from being open.

To sustain the development towards open electronic markets, the authors recognize different avenues: Göldi sees it primarily as a responsibility for academics to assure a more beneficial outcome of digital innovations for society as a whole. Schmid calls for open protocols for generic market services supporting the distinct phases of market transactions to realize open markets. This includes the need for a "personal data ecosystem" and self-determination of personal data as well as a legal environment to secure privacy. In the area of banking, Dratva addresses developments of financial markets as a form of electronic markets. Although "multibanking" solutions were already being discussed in the 1990s, it took another two decades until open banking concepts reached the banking industry. A major driver in the European Union was the Payment Services Directive (PSD2), which was initiated in 2017 and demands that banks provide other banks access to customer accounts (after authorization by customers). However, Dratva sees a long way for open banking solutions and states that today's "platform banking" offers a wider variety of services to customers without really being open in the sense of a global open market for banking.

An example that platforms in the financial industry are protected is provided by most financial exchanges. Although they are pioneers in introducing electronic trading systems, the participants are financial institutions and not consumers. Reck reports on this openness from two sides: on the one hand by achieving a high degree of transparency for all participants and on the other hand by safeguarding protective mechanisms to ensure the integrity of trading in volatile market situations and to create trustworthy electronic markets. He also points at the need to constantly enhance the functionality to avoid being whipsawed by competitors. Riemensperger and Falk confirm that this is challenging in markets where monopolistic structures already exist. They observe this situation in consumer industries with the dominating platform providers coming from the US and China. However, they believe that opportunities exist for European businesses in the B2B sector where smart products and its operating data are becoming important sources of competitive advantage. For this purpose, digital platforms need to take into account the specifics of B2B markets and use the potentials of open multi-sided platforms.
Linking to the evolution of electronic markets mentioned above, new technologies are potential sources of disruption. The role of artificial intelligence (AI) is mentioned in three contributions. First, Selz argues that AI technologies will become the new "nervous system" of any company in the future. While replacing human activities is possible, Selz sees large potential in "augmenting intelligence", which aims at supporting humans in their tasks. To enable and to control these potentials, the academic community is expected to retain the ability for self-reflection and the openness for approaches in favor of "a more beneficial outcome for society as a whole" as Göldi phrases it. Osterle even demands a shift of perspective and the foundation of a new discipline "Life Engineering" to counter the disadvantages that digital offerings are highly intransparent and individuals are helplessly exposed to applications based on machine intelligence utilizing the vast amount of (personal) data. Life engineering should focus on using technology to increase people's quality of life.

A similar argumentation is provided by Clarke. His study shows that information systems research in the field of electronic markets is dominated by single perspective research and is neglecting dual or even multi perspectives. In addition to the platform provider and his concerns for reaching critical mass, the participants as well as the nonparticipants should be considered. As (electronic) markets are embedded in societal systems, he advocates multiperspective research considering a broader range of not only market participants and to adopt additional views such as a social or environmental view. This ultimately is in line with the call for broadening research concepts in many of the research agendas from the literature (see Table 1).

\section{General research articles}

Besides introducing the format of shorter discussion papers, this jubilee issue gives birth to the new section "Fundamentals". Contrary to general research articles, which aim at advancing the knowledge base on digital platforms and electronic markets by presenting new findings, Fundamentals shall structure new topics of interest. Fundamentals should offer an understanding of the topic's relevance, its main characteristics, a definition, examples as well as an outlook. This issue presents the first three Fundamentals, which are on:

- Digital innovations. This Fundamental introduces the broad field of digital innovations, which have brought much disruption in the field of digital platforms. The authors Florian Wiesböck and Thomas Hess present four research streams, which they link to a framework that distinguishes three elements: Developing and implementing digital innovations, enabling digital 
innovations and governing digital innovations (Wiesböck and Hess 2020).

- Digital platform ecosystems. The authors Andreas Hein, Maximilian Schreieck, Tobias Riasanow, David Soto Setzke, Manuel Wiesche, Markus Böhm and Helmut Krcmar provide a structure on digital platform ecosystems that comprises three key elements (platform ownership, value-creating mechanisms, complementor autonomy) and four main research areas (Hein et al. 2020). The Fundamental adds to the evolution and research perspectives of digital platforms in this editorial (see Table 1).

Robotic process automation. Authored by Peter Hofmann, Caroline Samp and Nils Urbach, this Fundamental conducts a literature analysis in the field of robotic process automation (RPA) and describes the main characteristics of these software robots, including the functional classes (Hofmann et al. 2020). The authors show that RPA have important short- and longterm effects, in particular, when assuming further developments in AI technology. Although Fundamentals papers are not research papers in the original sense, they are literaturebased and feature a sound methodological structure. Ideally, they establish a solid foundation for research in the field of digital platforms and electronic markets. This leads to the four general research articles included in this issue. These are:

- "Emergence of collective digital innovations through the process of control point driven network reconfiguration and reframing: the case of mobile payment" by Boriana Rukanova, Mark de Reuver, Stefan Henningsson, Fatemeh Nikayin and Yao-Hua Tan. In their longitudinal in-depth case study of mobile banking in the Netherlands, the authors develop a framework that structures the process of how digital innovations are (successfully) brought to the market.

- "A taxonomy and archetypes of smart services for smart living" by Marcus Fischer, David Heim, Adrian Hofmann, Christian Janiesch, Christoph Klima and Axel Winkelmann. In their two-step approach, the authors first develop a taxonomy to structure smart services and then empirically analyze 100 smart services in the area of smart living to derive five archetypes.

- "Regret under different auction designs: the case of English and Dutch auctions" by Ninoslav Malekovic, Lazaros Goutas, Juliana Sutanto and Dennis Galletta. In an experimental setting the authors investigate the role of regret in the bidding for hotel room reservations. They find that regret depends on whether a Dutch or an English auction mechanism is used.

- "Buyer preferences for auction pricing rules in online outsourcing markets: fixed price vs. open price" by Zhijuan Hong, Ruhai Wu, Yan Sun and Kunxiang Dong. By adopting an empirical analysis, this paper examines whether buyers are more inclined to use open-price or fixed-prices auction formats. They show that the buyer's experience is important to understand such choices.

The editorial team of Electronic Markets wishes to thank all those who have been involved in making this jubilee issue possible. This not only goes to the authors of the 17 papers, but also to the many editors and reviewers who contributed in the review process.

\section{Development of the journal}

The editorial team also wishes to recognize the development of the journal Electronic Markets, which has been strong since the last jubilee issue in 2015. As summarized in Table 2, the number of submissions, papers published and final decisions almost doubled, which implied a significantly higher workload for the journal. It is a great achievement of all editors, board members, reviewers and authors that acceptance rate and the cycle time more or less remained stable. Hopefully, the increased number of institutions that have access to the journal and the more than doubled impact factor are indicators that research published in Electronic Markets has an impact. This impression is supported by the Top 4 articles by citations and downloads since 2015:

- "Smart tourism: foundations and developments" by Ulrike Gretzel, Marianna Sigala, Zheng Xiang and Chulmo Koo with 281 citations, 54,000 downloads (Gretzel et al. 2015).

- "Big data analytics in E-commerce: a systematic review and agenda for future research" by Shahriar Akter and Samuel Fosso-Wamba with 124 citations and 61,000 downloads (Akter and Fosso-Wamba 2016).

- "A definition for gamification: anchoring gamification in the service marketing literature" by Kai Huotari and Juho Hamari with 105 citations and 22,000 downloads (Huotari and Hamari 2017).

Table 2 Key metrics of Electronic Markets from 2015 and 2019

\begin{tabular}{lll}
\hline & 2015 & 2019 \\
\hline Number of submissions & 169 & 306 \\
Number of papers published & 29 & 47 \\
Number of downloads & 39,293 & 245,385 \\
Number of institutions with access & 7492 & 8481 \\
Acceptance rate absolute / relative & $26 / 16.0 \%$ & $58 / 19.1 \%$ \\
Cycle time until first decision & 51 days & 50.5 days \\
Final decisions (total) & 163 & 309 \\
Impact factor & 1.404 & 3.553 \\
\hline
\end{tabular}


- "Smart technologies for personalized experiences: a case study in the hospitality domain" by Barbara Neuhofer, Dimitrios Buhalis and Adele Ladkin with 109 citations and 5,168 downloads (Neuhofer et al. 2015).

For the future, we hope that the diffusion of Electronic Markets articles will further increase. An important element is the open access option, which as become broader availabe with RomeoGreen and compact agreements. The former allows the free publication of author version after a grace period of one year and the the latter grants open access to all authors from participating institutions (at present most universities in Austria, Germany, UK, Sweden and The Netherlands). We are very grateful for these developments and proud how the community has grown over the past five years. The time and effort the entire community has dedicated to the journal is not taken for granted and it is an honor that many colleagues decided to assume various responsibilites. We appreciate that our Associate Editor Robert Harmon from Portland State University followed the invitation to the position of a Senior Editor and that Thomas Hess from LudwigMaximilians-Universität Munich, who has been a member of Electronic Markets' editorial board has agreed to assume an Associate Editor position. Finally, two esteemed colleagues, who have already contributed several reviews and organized special issues are now members of the editorial board. We welcome Christy M.K. Cheung from Hong Kong Baptist University, and Manuel Trenz from University of Göttingen. With this we hope you enjoy reading this jubilee issue! Your EM-Team.

\section{Reviewers in 2019}

Abubakar Mohammed Abubakar

Ahmad Ghazawneh

Alex Norta

Ali Hajiha

Anastasia Constantelou

Anna Kolmykova

Aseem Kinra

Baolian Wang

Benjamin Spottke

Bharat Rao

Bruce William Weber

Christer Carlsson

Christian Schlereth

Christine Legner

Claudia Vienken

Daqing Gong

Dennis Marten Steininger

Dorina Rajanen

Eleftherios Iakovou

Esther Nagel

Fahim Akhter

Francisco-José Molina-Castillo

Giovanni Camponovo

Hannes Werthner

Harry Bouwman

Heinz-Theo Wagner

Hemang Subramanian

Henk Plessius

Ho Geun Lee

Ingrid Bauer

James E. Richard

Adam Vrechopoulos
Albrecht Fritzsche
Alexander Pflaum
Amar Anwar
Andreas Janson
Arne Buchwald
Babak Abedin
Barbara Keller
Benjamin Yen
Boris Otto
Buvaneshwaran Venugopal
Christian Engel
Christian Thiel
Christof Weinhardt
Cyrine Tangour
David Ziegler
Detlef Schoder
Doug Vogel
Eric-Oluf Svee
Eugenia de Matos Pedro
Felix Wortmann
Frédéric Georges Thiesse
Gregor Lenart
Hans Ulrich Buhl
Hassan Alsyed
Helena Alves
Hendra Zhicheng
Henry Kim
Hongxiu Li
Ivo Blohm
James Richard Wolf
Aation

Agata Filipowska
Alea Fairchild
Alfred Zimmermann
Amir Abbasi
Andreea Cristina Mihale-Wilson
Arthur Jin Lin
Bala Anand
Barbara Krumay
Bernd Skiera
Brenda Chawner
Caroline Chan
Christian Matt
Christiane Lehrer
Christopher Patrick Holland
Daniel Beimborn
Dennis Kundisch
Devashish Dasgupta
Efosa Carroll Idemudia
Erwin Fielt
Fabio Lobato
Florian Lüdeke-Freund
Gerrit Küstermann
Günter Prock1
Hans-Dieter Zimmermann
Heikki Hammainen
Helmut Krcmar
Henk de Vries
Herwig Winkler
Hyunwoo Park
Jaap Gordijn
James Yae




\begin{tabular}{|c|c|c|}
\hline Jan Fabian Ehmke & Jens Poeppelbuss & Jerry Fjermestad \\
\hline Jianwei Hou & Jin Kyun Lee & João Barata \\
\hline Johan Versendaal & John Jeansson & Jonas Hedman \\
\hline Joris Hulstijn & Jörn Altmann & José Parra Moyano \\
\hline Jouni Similä & Judith Gebauer & Juergen Moormann \\
\hline Jukka Ruohonen & Jukka T. Heikkila & Julia Boppert \\
\hline Julia Krönung & Julian Bühler & June $\mathrm{Lu}$ \\
\hline Jürgen Anke & Kalina Staykova & Karl Täuscher \\
\hline Katarina Stanoevska-Slobeva & Katharina Ebner & Kazem Haki \\
\hline Kim B. Serota & Koen Smit & Konstantinos Vergidis \\
\hline Krassie D. Petrova & Kyle B. Murray & Lailatul Faizah Abu Hassan \\
\hline Larry Shi & Lauri Wessel & Lawrence Fong \\
\hline Lei $\mathrm{Xu}$ & Leona Chandra Kruse & Luba Torlina \\
\hline Mahboobeh Harandi & Mahdi Atia & Maik Lange \\
\hline Makoto Nakayama & Manuele Kirsch-Pinheiro & Marc Burkhalter \\
\hline Marc T. P. Adam & Margherita Pero & Maria Madlberger \\
\hline Marianna Sigala & Marijn Janssen & Marikka Heikkilä \\
\hline Mark De Reuver & Markus Bick & Martin Franke \\
\hline Martin Smits & Martin Spann & Mathias Klier \\
\hline Mathieu Chanson & Matthias Meyer & Matthias Murawski \\
\hline Matthijs Berkhout & Matthijs Smakman & Matti Mäntymäki \\
\hline Mazen Ali & Michael Moehring & Michail Batikas \\
\hline Mijalche Santa & Mustafa Mosa & Nancy Wuenderlich \\
\hline Navin Sewberath Misser & Nestor Duch-Brown & Nilmini Wickramasinghe \\
\hline Nils Urbach & Nitza Geri & Nivedita Agarwal \\
\hline Nora Fteimi & Olaf Reinhold & Pan Zheng \\
\hline Pascal Mehrwald & Pascal Moriggl & Paul H. Timmers \\
\hline Paulo Duarte & Payam Hanafizadeh & Peter Gomber \\
\hline Petri Ahokangas & Pramoth Kumar Joseph & Priyan MK \\
\hline Qizhi Dai & Rainer Alt & Reima Suomi \\
\hline Reinhard Jung & Ricardo Buettner & Richard Glavee-Geo \\
\hline Robert Harmon & Roger Bons & Rogier van de Wetering \\
\hline Rüdiger Breitschwerdt & Rüdiger Grimm & Rudolf Vetschera \\
\hline Sabine Matook & Saied Mohamed & Sam Leewis \\
\hline Sam Solaimani & Samar I. Swaid & Samuel Fosso Wamba \\
\hline Sascha Weigel & Sebastian Haugk & Sebastian Späth \\
\hline Shahriar Akter & Shahrokh Nikou & Shahrooz Abghari \\
\hline Shengnan Han & Silvia Cachero-Martínez & Simon Albrecht \\
\hline Stan Karanasios & Stefan Huch & Stefan Morana \\
\hline Steven Bellman & Susanne Leist & Svenja Hagenhoff \\
\hline Tao Li & Theo Araujo & Thomas Hess \\
\hline Tianhang Huang & Tilo Böhmann & Timo Koivumäki \\
\hline Tingting Zhang & Tomi Dahlberg & Ully Gretzel \\
\hline Ulrike Baumöl & Ulrike E. Lechner & Uwe Leimstoll \\
\hline Val Anne Hooper & Valentin Holzwarth & Verena Dorner \\
\hline Victor Cheng & Vivek GN & Volker Bach \\
\hline W. Marc Lim & Wilfred Vincent Huang & Wim Hulsink \\
\hline Wolfgang Hommel & Wolfgang Maass & Xiwei Xu \\
\hline Yanling Chang & Yoshiaki Fukami & Yu Sun \\
\hline Yun Wan & Zeeshan Ahmed Bhatti & Zhimin Gao \\
\hline Zhiyong Liu & Zongwei Luo & \\
\hline
\end{tabular}

Acknowledgements The author acknowledges the valuable contributions and the feedback from Hans-Dieter Zimmermann, Maxi Herzog and Dorothee Ulrich to this comprehensive jubilee editorial.

Funding Information Open Access funding provided by Projekt DEAL.

Open Access This article is licensed under a Creative Commons Attribution 4.0 International License, which permits use, sharing, adaptation, distribution and reproduction in any medium or format, as long as you give appropriate credit to the original author(s) and the source, provide a link to the Creative Commons licence, and indicate if changes were made. The images or other third party material in this article are included in the article's Creative Commons licence, unless indicated otherwise in a credit line to the material. If material is not included in the article's Creative Commons licence and your intended use is not permitted by statutory regulation or exceeds the permitted use, you will need to 
obtain permission directly from the copyright holder. To view a copy of this licence, visit http://creativecommons.org/licenses/by/4.0/.

\section{References}

Abdelkafi, N., Raasch, C., Roth, A., \& Srinivasan, R. (2019). Multi-sided platforms. Electronic Markets, 29(4), 553-559. https://doi.org/10. 1007/s12525-019-00385-4.

Akter, S., \& Fosso-Wamba, S. (2016). Big data analytics in E-commerce: A systematic review and agenda for future research. Electronic Markets, 26(2), 173-194. https://doi.org/10.1007/s12525-0160219-0.

Alaimo, D. (2018). Online marketplace revenues to double by 2022. Retaildive. May 17, https://www.retaildive.com/news/onlinemarketplace-revenues-to-double-by-2022/ (accessed February 18, 2020).

Allen, D. (1988). New telecommunications services: Network externalities and critical mass. Telecommunications Policy, 12(3), 257-271. https://doi.org/10.1016/0308-5961(88)90024-9.

Alt, R. (2018). Electronic Markets on digitalization. Electronic Markets, 28(4), 397-402. https://doi.org/10.1007/s12525-018-0320-7.

Alt, R., \& Klein, S. (1999). Lessons in electronic commerce: The case of electronic transportation markets. Failure \& Lessons Learned in Information Technology Management, 3(3), 81-93. https://doi.org/ $10.3727 / 108812899791784512$.

Alt, R. \& Klein, S. (2011) Twenty years of electronic markets researchlooking backwards towards the future. Electronic Markets 21 (1), 41-51, https://doi.org/10.1007/s12525-011-0057-z.

Alt, R., \& Österle, H. (2014). Editorial 24/1: Electronic Markets and practice-orientation. Electronic Markets, 24(1), 1-3. https://doi. org/10.1007/s12525-014-0152-z.

Alt, R., \& Zimmermann, H.-D. (2014). Editorial 24/3: Electronic Markets and general research. Electronic Markets, 24(3), 161-164. https:// doi.org/10.1007/s12525-014-0163-9.

Alt, R., \& Zimmermann, H.-D. (2015). Editorial 25/3: Electronic Markets on ecosystems and tourism. Electronic Markets, 25(3), 169-174. https://doi.org/10.1007/s12525-015-0197-7.

Alt, R., \& Zimmermann, H.-D. (2019). Electronic markets on platform competition. Electronic Markets, 29(2), 143-149. https://doi.org/10. 1007/s12525-019-00353-y.

Alt, R., Militzer-Horstmann, C., \& Zimmermann, H.-D. (2015). 25 years of Electronic Markets. Electronic Markets, 25(1), 1-5. https://doi. org/10.1007/s12525-015-0185-y.

Ardolino, M., Saccani, N., \& Perona, M. (2016). The analysis of multisided platforms: results from a literature review. Proceedings Spring Servitization Conference, British Academy of Management, Manchester.

Asadullah, A., Faik, I., \& Kankanhalli, A. (2018). Digital platforms: A review and future directions. Proceedings Pacific-Asia conference on information systems (PACIS). https://aisel.aisnet.org/pacis2018/ $248 /$.

Berg, C., Davidson, S., \& Potts, J. (2019). Blockchain technology as economic infrastructure: Revisiting the electronic markets hypothesis. Frontiers in Blockchain, 2. https://doi.org/10.3389/fbloc.2019. 00022

Berlecon (2000). B2B-Marktplatzdatenbank. Berlecon Research, http:// www.berlecon.de/services/b2bdb/eingang.php. (accessed 8, August 2000.)

Böger, M., Wecht, C. H. \& Stalder, C. (2019). Hybrid business platforms - Marketplaces of the future. Marketing review St. Gallen 2, 38-44. http://www.alexandria.unisg.ch/publications/256919 (accessed February 17, 2020).
Booking.com. (2020). Trip terms and conditions. Amsterdam: Booking.com B.V https://www.booking.com/content/terms.html.

Cheng, K. (2016). Firm boundary and performance in the airline ticket distribution industry: Effects of the evolution of electronic markets. Travel and Tourism Research Association: Advancing Tourism Research Globally. 23. https://scholarworks.umass.edu/ttra/2010/ Oral $/ 23$.

Clarke, R. (2020). Researcher perspectives in Electronic Markets. Electronic Markets, 30(1). http://www.rogerclarke.com/EC/RPEM. $\mathrm{html}$

Clemons, E. K., Reddi, S. P., \& Row, M. C. (1993). The impact of information technology on the organization of economic activity: The 'move to the middle' hypothesis. Journal of Management Information Systems, 10(2), 9-35. https://doi.org/10.1080/ 07421222.1993 .11517998$.

Coyle, D. (2016). Making the most of platforms: A policy research agenda. SSRN Electronic Journal. https://doi.org/10.2139/ssrn.2857188.

Cusumano, M. A. (2020). 'Platformizing' a bad business does not make it a good business. Communications of the ACM, 63(1), 23-25. https:// doi.org/10.1145/3372918.

de Reuver, M., Sørensen, C., \& Basole, R. C. (2018). The digital platform: A research agenda. Journal of Information Technology, 33(2), 124-135. https://doi.org/10.1057/s41265-016-0033-3.

Demary, V., \& Rusche, C. (2018). The economics of platforms. Research report, German Economic Institute, Cologne. http:/hdl.handle.net/ $10419 / 182531$.

Dratva, R. (2020). Is open banking driving the financial industry towards a true electronic market? Electronic Markets, 30(1). https://doi.org/ 10.1007/s12525-020-00403-w.

Ecommerce Germany. (2019). 12 leading marketplaces in Europe, Ecommerce Germany, https://ecommercegermany.com/blog/12leading-marketplaces-europe (accessed February 17, 2020).

eMarketer. (2019). Global ecommerce 2019. eMarketer Inc., New York (NY). https://www.emarketer.com/content/global-ecommerce-2019 (accessed January, 4, 2020).

Evans, D. S., \& Schmalensee, R. (2016). Matchmakers: The new economics of multisided platforms. Boston (MA): Harvard Business Review Press.

Forbes. (2019). The world's largest public companies. https://www. forbes.com/global2000/list/\#header:marketValue_sortreverse:true (accessed, January, 4, 2020).

Glassberg, B. C., \& Merhout, J. W. (2007). Electronic markets hypothesis redux: Where are we now? Communications of the ACM, 50(2), 5155. https://doi.org/10.1145/1216016.1216020.

Göldi, A. (2020). A blind spot for the dark side: The monopolies we didn't see coming. Electronic Markets, 30(1). https://doi.org/10. 1007/s12525-020-00402-x.

Green, D. (2019). Target is taking a page out of Amazon's playbook But it could face some challenges. Business Inside, February 25. https://www.businessinsider.com/target-debuts-marketplace-vsamazon-walmart-2019-2 (accessed February, 17, 2020).

Gretzel, U., Sigala, M., Xiang, Z., \& Koo, C. (2015). Smart tourism: Foundations and developments. Electronic Markets, 25(3), 179188. https://doi.org/10.1007/s12525-015-0196-8.

Grieger, M. (2003). Electronic marketplaces: A literature review and a call for supply chain management research. European Journal of Operational Research, 144(2), 280-294. https://doi.org/10.1016/ S0377-2217(02)00394-6.

Hein, A., Schreieck, M., Riasanow, T., Setzke, D. S., Wiesche, M., Böhm, M., \& Krcmar, H. (2020). Digital platform ecosystems. Electronic Markets, 30(1). https://doi.org/10.1007/s12525-019-00377-4.

Hofmann, P., Samp, C., \& Urbach, N. (2020). Robotic process automation. Electronic Markets, 30(1). https://doi.org/10.1007/s12525019-00365-8. 
Howcroft, D., \& Bergvall-Kåreborn, B. (2019). A typology of crowdwork platforms. Work, Employment and Society, 33(1), 2138. https://doi.org/10.1177/0950017018760136.

Huotari, K., \& Hamari, J. (2017). A definition for gamification: Anchoring gamification in the service marketing literature. Electronic Markets, 27(1), 21-31. https://doi.org/10.1007/s12525015-0212-z.

Kenney, M., \& Zysman, J. (2016). The rise of the platform economy. Issues in Science and Technology, 32(3), 61-69.

Klein, S., \& Alt, R. (2015). B2B electronic markets. In R. Mansell \& P.$\mathrm{H}$. Ang (Eds.), The international encyclopedia of digital communication and society (pp. 35-46). Malden/Oxford: Wiley Blackwell. https://doi.org/10.1002/9781118767771.wbiedcs072.

Malone, T. W., \& Laubacher, R. J. (1998). The dawn of the e-lance economy. Harvard Business Review, 76(5), 144-152.

Malone, T. W., Yates, J., \& Benjamin, R. I. (1987). Electronic markets and electronic hierarchies. Communications of the ACM, 30(6), 484-497. https://doi.org/10.1145/214762.214766.

Neuhofer, B., Buhalis, D., \& Ladkin, A. (2015). Smart technologies for personalized experiences: A case study in the hospitality domain. Electronic Markets, 25(3), 243-254. https://doi.org/10.1007/ s12525-015-0182-1.

Osterle, H. (2020). Life engineering. Electronic Markets, 30(1). https:// doi.org/10.1007/s12525-019-00388-1.

Parker, G. G., van Alstyne, M. W., \& Choudary, S. P. (2016). Platform revolution: How networked markets are transforming the economy and how to make them work for you. New York/London: Norton.

Philips, A. (2020). Does the book have a future? In S. Eliot \& J. Rose (Eds.), A companion to the history of the book (2nd ed.). Chichester: Wiley. https://doi.org/10.1002/9781119018193.ch56.

Pucihar, A. (2020). The digital transformation journey: Content analysis of electronic markets articles and bled eConference proceedings from 2012 to 2019. Electronic Markets, 30(1). https://doi.org/10. 1007/s12525-020-00406-7

Puschmann, T., \& Alt, R. (2016). Sharing economy. Business \& Information Systems Engineering, 58(1), 93-99. https://doi.org/10. 1007/s12599-015-0420-2.

Reck, M. (2020). Xetra: The evolution of an electronic market. Electronic Markets, 30(1). https://doi.org/10.1007/s12525-020-00399-3.

Riemensperger, F., \& Falk, S. (2020). How to capture the B2B platform opportunity. Electronic Markets, 30(1). https://doi.org/10.1007/ s12525-019-00390-7.

Ritala, P., Golnam, A., \& Wegmann, A. (2014). Coopetition-based business models: The case of Amazon.com. Industrial Marketing Management, 43(2), 236-249. https://doi.org/10.1016/j. indmarman.2013.11.005.

Rong, K., Lin, Y., Li, B., Burström, T., Butel, L., \& Yu, J. (2018). Business ecosystem research agenda: More dynamic, more embedded, and more internationalized. Asian Business and Management, 17(3), 167-182. https://doi.org/10.1057/s41291-0180038-6.

Sánchez-Cartas, J.M. \& León, G. (2019). Multi-sided platforms and markets: a literature review. https://www.researchgate.net/publication/ 325225786 (accessed February 18, 2020).

Schmid, B. (2020). What kind of electronic markets do we deserve? Electronic Markets, 30(1). https://doi.org/10.1007/s12525-02000400-z.

Selz, D. (2020). From electronic markets to data driven insights. Electronic Markets, 30(1). https://doi.org/10.1007/s12525-01900393-4.

Setzke, D. S., Böhm, M. \& Krcmar, H. (2019). Platform openness: A systematic literature review and avenues for future research. Proceedings international conference on Wirtschaftsinformatik (WI). https://aisel.aisnet.org/wi2019/track07/papers/9.

Standing, S., Standing, C., \& Love, P. E. D. (2010). A review of research on e-marketplaces 1997-2008. Decision Support Systems, 49(1), 41-51. https://doi.org/10.1016/j.dss.2009.12.008.

Staykova, K. S. \& Damsgaard, J. (2014). A model of digital payment infrastructure formation and development: The EU regulator's perspective. Proceedings international conference on Mobile business (ICMB). http://aisel.aisnet.org/icmb2014/14.

Tiwana, A. (2014). Platform ecosystems: Aligning architecture, governance, and strategy. Burlington: Morgan Kaufmann, Amsterdam etc.

van Alstyne, M. W., Parker, G. G. \& Choudary, S. P. (2016). Pipelines, platforms, and the new rules of strategy. Harvard Business Review 94(4), 54-62.

Vial, G. (2019). Understanding digital transformation: A review and a research agenda. Journal of Strategic Information Systems, 28(2), 118-144. https://doi.org/10.1016/j.jsis.2019.01.003.

vom Brocke, J., \& Maedche, A. (2019). The DSR grid: Six core dimensions for effectively planning and communicating design science research projects. Electronic Markets, 29(3), 379-385. https://doi. org/10.1007/s12525-019-00358-7.

Wiesböck, F., \& Hess, T. (2020). Digital innovations. Electronic Markets, 30(1). https://doi.org/10.1007/s12525-019-00364-9.

Wigand, R. T. (2020). Whatever happened to disintermediation. Electronic Markets, 30(1).

Yoffie, D. B., Gawer, A., \& Cusumano, M. A. (2019). A study of more than 250 platforms reveals why most fail. Harvard Business Review Digital Articles, (May 29). https://hbr.org/2019/05/a-study-of-morethan-250-platforms-reveals-why-most-fail.

Publisher's note Springer Nature remains neutral with regard to jurisdictional claims in published maps and institutional affiliations. 